\title{
Funeral Processes During the COVID-19 Pandemic: Perceptions Among Islamic Religious Leaders in Indonesia
}

\author{
Nurhayati Nurhayati ${ }^{1}$ [D $\cdot$ Tri Bayu Purnama ${ }^{1,2}$
}

Accepted: 27 August 2021 / Published online: 1 September 2021

(C) The Author(s), under exclusive licence to Springer Science+Business Media, LLC, part of Springer Nature 2021

\begin{abstract}
Controversies surrounding the handling of corpses have been amplified during the present COVID-19 pandemic. According to Indonesian scholars, certain perspectives driving these controversies inhibit the implementation of health protocols issued by the government. This study comprehensively explores the diverse perceptions and responses of religious leaders regarding COVID-19 funeral management. Participants comprised six scholars from major Islamic religious organizations, two community leaders, and two families representing COVID-19 patients. Furthermore, content analysis was used to analyze the data. The results showed that the religious leaders, all men aged over 50 years, supported the health directives designed to reduce high transmission risk. However, there were substantial disparities in corpse preparation processes, potentially due to organizational beliefs around burial rites. Some religious leaders aligned their protocols with their religious beliefs. Conversely, families of the deceased insisted that the approved protocol for handling corpses went against their religious and cultural values. Therefore, promotion of protocols and coordination among the government, religious leaders, and the community are needed to decrease the misperceptions and misinformation surrounding the new COVID-19 funeral protocols.
\end{abstract}

Keywords Funeral processions $\cdot$ COVID-19 $\cdot$ Religious leaders $\cdot$ Islam

Nurhayati Nurhayati

nurhayati@uinsu.ac.id

1 Faculty of Public Health, Universitas Islam Negeri Sumatera Utara, J1 IAIN, Gaharu, Medan, Indonesia

2 Southeast Asian Ministers of Education Organization Regional Centre for Food and Nutrition/Pusat Kajian Gizi Regional UI, East Jakarta, Indonesia 


\section{Introduction}

The COVID-19 pandemic is a major global health challenge that requires comprehensive control to inhibit viral spread (World Health Organization (WHO), 2020; Xinguang \& Yu, 2020). The pandemic was triggered by the development of animal-to-animal diseases (zoonosis) and their mutation to human-to-human infections with exponential transmission rates (Gao et al., 2020; Weiss \& Murdoch, 2020). Official reports on April 12, 2021, estimated the number of confirmed COVID-19 cases in Indonesia to be 1,571,824, with 42,656 deaths (Indonesian COVID-19 Task Force, 2021). The virus has had significant and complex impacts across Indonesia, prompting the government to prepare comprehensive directives.

The Indonesian government has identified religious perspectives as critical to its COVID-19 response (Indonesian COVID-19 Task Force, 2020). This is because religious leaders or scholars have played an important role in controlling the spread of the pandemic (Charzyńska, 2015; Hall et al., 2008). Furthermore, the international literature has highlighted the importance of considering religious leaders' opinions when developing health policy. For instance, in Saudi Arabia, Hajj and Umrah (pilgrims) must obtain recommendations from religious leaders for certain vaccines to participate in holy activities (Ahmed et al., 2006; Memish et al., 2012; Pane et al., 2019). Other religious approaches have been adopted to promote behavioral change toward public health challenges, including HIV-AIDS (Cotton et al., 2006; Gray, 2004; Noden et al., 2010; Zou et al., 2009), mental health (Koenig, 2009; Moreira-Almeida et al., 2006), and nutrition (Persynaki et al., 2017; Trepanowski \& Bloomer, 2010). The inclusion of religious approaches by consulting with high-profile religious leaders regarding health interventions effectively increases public awareness (Cyphers et al., 2017; RiveraHernandez, 2014). Additionally, negative actions from religious leaders can be divisive and thereby exacerbate public health problems. Therefore, improper actions, such as opposing social restrictions and the closure of religious places, can inhibit community acceptance of COVID-19 policy implementation (Alimardani \& Elswah, 2020; Hashmi et al., 2020; Yoosefi Lebni et al., 2021).

On April 30, 2020, the Indonesian government attributed 792 deaths in 34 provinces to COVID-19 (Indonesian COVID-19 Task Force, 2020). As a result, a detailed health protocol was established by the government through the Ministries of Religion and Health. Subsequently, there has been a significant increase in community rejection of funerals conducted according to approved burial protocols. This is due to the alleged incompatibility of the new burial requirements with long-held and important religious and cultural values (Richards et al., 2015). The risk of new viral clusters is exacerbated by this rejection of protocolinformed burials. For instance, Indonesia has seen a rise in independent corpse handling without medical or health officer assistance. It is clear that these practices are influenced by misperceptions and misinformation (Purnama et al., 2020).

In Islamic tradition, lifeless bodies are handled through bathing, shrouding, praying, burying, and offering prayers (Ahaddour et al., 2017; Al-Shahri et al., 
2007). In the context of COVID-19, this process is strictly supervised by an expert team that includes medical and health officers (Rewar \& Mirdha, 2014; Tiffany et al., 2017). Consequently, the opportunities for families to pay final respects and conduct specific religious rituals are limited. There have been forceful retrieval of bodies from government-sanctioned funeral processes and community rejection of protocols in various regions across Indonesia. Activities that occur after burials with large crowds, such as prayer ceremonies, are thought to have triggered new clusters of the virus (Tiffany et al., 2017). Although the government insists on the COVID-19 directives, certain religious leaders support reclamation of those who died from COVID-19 and independent traditional care processes without strict health supervision. Since some patients with COVID-19 can be asymptomatic, there is high potential to spread the virus during the performance of these independent rituals.

Evidence on the rejection of COVID-19 patient burial rites has emerged in Indonesia (Nurhayati Tri Bayu Purnama, 2020). Furthermore, misinformation on the implementation of these health rules has been disseminated in communities, and religious leaders appear opposed to the government's disease control strategy (Nurhayati Tri Bayu Purnama, 2020). Therefore, this study investigates Muslim leaders' perceptions of the proper handling of COVID-19 corpses. Moreover, it evaluates problems with the current pandemic protocols from the perspectives of religious and community leaders and the families of patients. The results show the potential impact of religious rituals on COVID-19 prevention and the potential to reduce transmission.

\section{Religious Leaders: An Islamic Perspective}

In Indonesia, the term for religious leaders, or scholars, is derived from the Arabic word alima, meaning 'to know' (Ma'luf, 1987). The word scholar is associated with a person with morals, hadith, tawhid, jurisprudence, or religious sciences. Additionally, it points to people who understand natural and social sciences, including economics, medicine, and technology. This is supported by the word of Allah in the letter Fathir (35):28: "Just as people, living beings, and cattle are of various colors as well."

A scholar is a role model and leader in the community, as achieved by the Prophet Muhammad SAW in leading Muslims. Islamic teachings see no need to separate scholars and the government (umara ') because both work together for their peoples' benefit and welfare. However, an understanding of the perspectives of religious leaders is urgently required to obtain insight into the dangers of the further spread of COVID-19 due to spiritual and religious activities.

\section{Caring for a Corpse in Islam}

There are specific concepts and values in Islam regarding the preparation of corpses. Muslims adhere to a principle of sufficient care, and following Islamic sharia is crucial and part of the respect and honor due to a human being (Al-Shahri et al., 2007). 
For instance, the community recognizes that the bathing stage of burial is regulated in Islamic teachings to reflect respect for the corpse (Richards et al., 2015). This process commences with washing, which is fardlu kifayah (mandatory for Muslims), and is performed by the deceased's closest family. Bathing is followed by wrapping the body with a long, white cloth, based on the rules set forth by the Prophet Muhammad in the hadith: "If one of you covers his brother, then let him shroud it properly" (Narrated by Ahmad, Muslim, and Abu Daud of Jabir). Subsequent phases involve offering prayers for the dead.

Burial is the last step of caring for the body, and the hadith states the legal basis:

Whoever witnesses the body until it is converted to prayer, then he gets the reward of one qirath. And whoever witnesses it until it is buried, then he will be rewarded with two qiraths. Asked: 'What are the two qiraths?' The Prophet replied: "Like two big hills'" (Narrated by al-Bukhari and Muslim, from Abu Hurairah) (Al-Zubaydi et al., 2001).

Each step of the care process has a deep message and value for Muslims. Ultimately, social responsibility is critical to this process, and this ritual has become a cultural activity in Indonesian Muslim society.

\section{Caring for a Corpse in Islam in Emergency Conditions}

Under usual conditions, the corpse is handled in line with the teachings exemplified by the Prophet Muhammad. In emergency cases, such as during natural disasters, disease outbreaks, and other similar conditions, this process should minimize the adverse effect on humans or martyrdom (Ahmed Al-Dawoody, 2020). The COVID19 crisis represents an emergency situation and consequently allows exceptions to normal conditions, determined based on scholarly opinion. For instance, normal corpse bathing is performed by tayammum following sharia and involves cleansing. However, because of medical considerations concerning safety and the possible transmission of COVID-19, the body is not allowed to be bathed or to undergo tayammum, as stipulated by dharurat syar'iyyah (Hirji, 2020; The Republic of Indonesia Ministry of Religious Affairs, 2020a).

COVID-19 corpses are buried using the following procedure. After washing or tayammum, or not, due to the dharurah syar'iyyah, the corpse is covered with a cloth and placed in a safe and impermeable bag as a safeguard and to prevent viral spread (The Republic of Indonesia Ministry of Religious Affairs, 2020a). Subsequently, it is placed into a waterproof and air-repellent coffin tilted to the right; the coffin should face Qibla when buried.

The law for funeral prayer is fardhu kifayah. The prayer is applied immediately to the deceased after being covered, according to sunnah. This practice is performed in a safe place by at least one person to avoid further viral spread. In the absence of these conditions, the corpse is prayed for before or after burial, and where this is impossible, a recitation from afar, called ghaib prayer, is observed. The person or party performing the funeral prayers must be vigilant and guard against possible virus transmission by observing government-established health protocols. 
The procedure for burying a COVID-19 corpse is regulated by the Indonesian Ulema Council (MUI) Fatwa Number 18 of 2020 and the circular of the Directorate General of the Islamic Community. Based on the MUI Fatwa, the funeral should be conducted following the provisions of Sharia and medical protocols. The corpse, previously subjected to medical regulations, is immediately placed in a coffin and lowered into the grave without opening the chest, plastic, or shrouds. Furthermore, placing multiple bodies in one grave is allowed, according to the provisions for aldharurah al-syar'iyyah or an emergency situation (Indonesian Muslim Council, 2020). Cremation is unnecessary, as burying the body according to the established procedure does not endanger residents (The Republic of Indonesia Ministry of Religious Affairs, 2020b).

\section{Methods}

\section{Study Setting}

This study used a qualitative case study to determine the perceptions and responses of religious leaders regarding the issue of caring for COVID-19 corpses in North Sumatra Province between June and September 2020. Additionally, it explored the perspectives of religious leaders or scholars from various regional Islamic community organizations, including Nahdatul Ulama, Muhammadiyah, Al-Washliyah, Al-Ittihadiyah, and the Indonesian Ulema Council. The study also sought the perspectives of family members of COVID-19 patients and community leaders on funeral or burial processes. Participants were asked to describe corpse management in line with their organizational positions and propose responses to community resistance to government protocols.

\section{Participants}

Participants comprised religious leaders in several related organizations who were known as scholars and had significant leadership roles. A total of 6 scholars or religious leaders aged between 40 and 70 participated, each from different religious organizations. Moreover, all participants were male, and in terms of education, they had master's degrees in religion and doctorates in fiqh and philosophy aqidah; some were professors in $d a$ 'wah and education fields. This study interviewed two traditional or community leaders in North Sumatra Province with a master's and doctoral degree in sociology or anthropology for each community leader. Additionally, two families of COVID-19 patients who had died participated. These in-depth interviews accommodated more extensive valid data collection opportunities than what could have been achieved via a questionnaire with closed questions and predetermined answers. 


\section{Data Collection}

Permission to conduct this study was sought from religious and community organizations. Additionally, participant consent was obtained from the families interviewed and community leaders. Data were collected using in-depth interviews conducted through telephone calls that lasted approximately 30-45 minutes and were digitally recorded using a mobile phone. Furthermore, trustworthiness was achieved by triangulating data from scholars, community members, and leaders.

\section{Research Instruments}

The structured interview guide for the religious leaders was organized into three sections. The first section related to demographics, including age, gender, highest education level achieved, and Islamic organization. The second section captured the interviewees' perceptions around monitoring corpses in emergency situations and the information sources acquired from the community regarding handling dead bodies. The third section examined the scholars' views and fatwas based on the COVID-19 burial protocols. The study sought to understand their opinions on the COVID-19 burial protocol and whether it could curb disease spread. Additionally, scholars were asked why they think the protocol reduces the sacredness of Islamic burial rites. The third section explored potential solutions to reducing the complexities of scholars' responses for the community. One of the solutions was adapting the government's COVID-19 procedures to local religious, social, and cultural values.

A structured interview guide for community leaders was also employed in which the questions posed related to the socioreligious aspects of corpse monitoring. Moreover, a different interview schedule elicited information from families of COVID-19 patients regarding their attitudes and experiences.

\section{Data Analysis}

The in-depth telephone interviews were digitally recorded, transcribed, grouped based on manual coding, and analyzed using thematic analysis. The interview transcripts and interviewer notes were subjected to open coding. Moreover, the themes were described by the codes developed by the research team for substantive interpretation before analysis. The results relating to the main theme were described to identify and resolve any conflicting opinions. The three themes in this study were the rejection and lack of religious leader assistance, different understandings of the funeral process, and perceptions of religious leaders. Content analysis was used to understand the informant responses and to deepen the content. This was due to the high variation in answers from each informant and religious organization. 


\section{Ethical Concerns and Flexibility}

This study received ethical approval from the Health Research Ethics Committee of the Faculty of Medicine, Islamic University of North Sumatra. Furthermore, all participants consented to participate in this research before the interviews.

\section{Results}

This section describes the three central themes (Table 1) related to funeral processes for COVID-19 patients and Islamic religious leaders' perceptions. The themes include the rejection and lack of religious leader assistance, different understandings of the funeral process, and perceptions of religious leaders. Selected quotations from the participant interviews appear in italics with identification numbers to preserve confidentiality.

\section{Rejection of COVID-19 Protocols and Lack of Religious Leader Support for Patients' Families}

Six religious leaders aged between 47 and 70 from different religious organizations, including Nahdatul Ulama, Muhammadiyah, Al-Wasliyah, and the Provincial Indonesian Ulema Council, participated in this study. Two of the community leaders had sociology and cultural education degrees. The family members of COVID-19 patients were all female, aged younger than 50, and working as homemakers. Data saturation was reached following the interviewing of six participants. Therefore, more participants were recruited (Table 2).

This study showed that families did not receive education and counseling from religious leaders, leading them to refuse to acknowledge COVID-19 protocols. For these participants, COVID-19 corpse preparation was significantly different from corpse care under normal conditions. The new protocols meant that families and the community could no longer be involved.

Table 1 Themes and categories based on responses from religious and community leaders and families

\begin{tabular}{ll}
\hline Themes & Categories \\
\hline $\begin{array}{l}\text { Rejection of COVID-19 protocols and lack of reli- } \\
\text { gious leader support for patients' families }\end{array}$ & $\begin{array}{c}\text { Families of COVID-19 patients refuse medical } \\
\text { diagnoses } \\
\text { Society rejects the burial process due to a lack of } \\
\text { COVID-19 knowledge }\end{array}$ \\
$\begin{array}{l}\text { Different understandings of religious leaders } \\
\text { about the funeral process during the COVID-19 } \\
\text { pandemic }\end{array}$ & $\begin{array}{l}\text { Religious leaders have different understandings of } \\
\text { funeral processes due to diverse opinions among } \\
\text { health experts and the variety of disseminated } \\
\text { information }\end{array}$ \\
$\begin{array}{l}\text { Perceptions of religious leaders around COVID-19 } \\
\text { deaths }\end{array}$ & $\begin{array}{c}\text { Government and religious leaders intend to take } \\
\text { responsibility }\end{array}$ \\
\hline
\end{tabular}


Table 2 Demographics of the study participants

\begin{tabular}{|c|c|c|c|c|c|c|c|c|}
\hline Religious leader & $N$ & $\%$ & Community leader & $N$ & $\%$ & Family member & $N$ & $\%$ \\
\hline \multicolumn{9}{|l|}{ Sex } \\
\hline Male & 6 & 100 & Male & 2 & 100 & Male & 0 & 0 \\
\hline Female & 0 & 0 & Female & 0 & 0 & Female & 2 & 100 \\
\hline \multicolumn{9}{|l|}{ Age } \\
\hline$<50$ y.o & 1 & 16.7 & $<50$ y.o & 0 & 0 & $<50$ y.o & 2 & 100 \\
\hline$\geq 50$ y.o & 5 & 83.3 & $\geq 50$ y.o & 2 & 100 & $\geq 50$ y.o & 0 & 0 \\
\hline \multicolumn{9}{|l|}{ Occupation } \\
\hline Public servant & 4 & 66.7 & Public servant & 1 & 50 & Homemaker & 2 & 100 \\
\hline $\begin{array}{l}\text { Non-governmental } \\
\text { organization }\end{array}$ & 2 & 33.3 & $\begin{array}{l}\text { Non-governmental } \\
\text { organization }\end{array}$ & 1 & 50 & Private sector & 0 & 0 \\
\hline \multicolumn{9}{|l|}{ Education } \\
\hline Bachelor's & 0 & 0 & Bachelor's & 0 & 0 & Elementary school & 0 & 0 \\
\hline Master's & 2 & 33.3 & Master's & 1 & 50 & Junior high school & 0 & 0 \\
\hline Doctorate & 3 & 50.0 & Doctorate & 1 & 50 & Senior high school & 2 & 100 \\
\hline Professor & 1 & 16.7 & Professor & 0 & 0 & University & 0 & 0 \\
\hline
\end{tabular}

Sad and hurt, because they (ordinary people) cannot express their sadness or the family even, as though it is kept secret because they cannot come and see. Also, they do not attend the funeral, that is what makes the family sad. (Family of Patient 1, female, 47 years)

Cannot see the family (COVID-19 patient) and be buried directly. Because corpses cannot be brought home directly. (Family of Patient 2, female, 34 years)

The rejection of COVID-19 protocols by the community was influenced by the negative stigma attached to corpse management. Participants understood that the deceased's relatives are expected to pay final respects, as is appropriate in Islam, despite protocol requirements.

Government policy is to isolate burial places far from family residences, which is considered dishonorable and is rejected by the family. (Community Leader 2, male, 52 years)

Because my brother was not (diagnosed as having) COVID-19, why should he be COVID-19 buried (according to COVID-19 burial protocol). Then, they (hospital staff) told the family to go home. And the patient was secretly brought out and buried by COVID-19 (according to COVID-19 burial protocol). (Family of Patient 1, female, 47 years)

This rejection was caused by the inability of families to fully accept medical diagnoses, which ultimately influenced the opinions of community and religious leaders. Family members indicated that religious leaders were not involved in the funeral rites and burial of their loved ones. 
They have never heard of a scholar (regarding COVID-19 burial education), they do not know what the scholars think (about COVID-19 burial protocol). They have never consulted with or heard from a scholar. (Family of Patient 2, female, 34 years).

Families acknowledged COVID-19 procedures only under the provision of a religious corpse preparation service in line with the rules of fiqh. Awareness of government regulations created initial capital for building public trust. This led the community leaders to realize that religious leaders did not offer, formally or informally, support for corpse care according to the health protocols. Therefore, the diverse religious views and dynamic socioreligious conditions required comprehensive education and understanding among all involved.

Families follow the procedure because it (the COVID-19 burial protocol) has been regulated by the government. (Family of Patient 1, female, 47 years)

Through informal channels, they still convey it (the COVID-19 burial protocol) to religious, community, and traditional leaders. (Community Leader 1 , male, 62 years)

Religious services for corpse preparation and effective educational models in the community were useful in implementing the COVID-19 directives. In this case, religious leaders were responsible for ensuring that community members complied with government regulations.

\section{Differences in the Understanding of Religious Leaders Regarding Funeral Processes During COVID-19}

This study highlighted disparities in the experience of religious leaders concerning corpse care processes. Scholars understood that the COVID-19 protocol was designed to reduce possible transmission, although certain clerics had varying opinions.

When they look at (the COVID-19 burial protocol), the COVID-19 protocol shows that people exposed to COVID-19 could still transmit it (COVID-19) 3-5 hours after death. (Religious Figure 3, male, 61 years)

Community leaders recognized knowledge differences among religious leaders, influenced by disparities in the information disseminated.

Most religious leaders reject the COVID-19 procedure due to differences in understanding and knowledge of this infectious disease (COVID-19). (Community Leader 1, male, 62 years)

Religious leaders understood that this variation was due to the diverse opinions of health experts regarding the transmission of COVID-19 through funerals. Therefore, the crucial point was transparency in implementing sharia corpse preparation processes, including bathing, covering, praying, burying, and offering condolences. 
They do not understand. In the initial information, there were differences of opinion from experts whether the dead were still infectious or not. (Religion Leader 6, male, 51 years)

Fardhu kifayah, especially for Muslims, has not been perfectly implemented by the hospital (sharia corpse care processes). This (the funeral process) caused distrust in the community. Now, the implementation of fardhu kifayah in hospitals is witnessed by families from afar with a restrictive protocol. (Community Leader 2, male, 52 years)

Prohibiting the public spread of false information, including by religious leaders, minimized community rejection of the COVID-19 protocol. Additionally, scholars' active role through official sources was crucial in reducing knowledge disparities among religious leaders regarding the handling of corpses.

\section{Perceptions of Religious Leaders Regarding COVID-19 Deaths}

All the scholars and religious leaders stated that funerals, according to the health protocols issued by the authorities, should be conducted with consideration of potential disease transmission. Some Islamic organizations had developed their own guidelines for COVID-19 by modifying the religious values of certain institutions to prevent the spread of the infectious disease.

For example, the corpse burial already has protocols (COVID-19 protocol). Based on the protocol, transmission to others is no longer possible (from the deceased COVID-19 body to other people). (Religious Leader 1, male, 43 years)

In Muhammadiyah, there is also a COVID-19 burial protocol agreed upon nationally and internationally. Therefore, they follow those burial rules. (Religious Leader 2, male, 65 years)

The religious organizations have care teams trained on COVID-19 procedures throughout the hospital network. However, corpse care in society continues to be driven by existing values and norms.

Protocol (COVID-19 burial protocol) has been established and confirmed by the Indonesian Ulama Council regarding the handling of such a corpse; it is no longer brought home, treated as normal; bathed, dipped, etc. When allowed (non-COVID-19 burial protocol), this has the potential to be infectious. Therefore, COVID-19 patients are immediately treated at the hospital and taken directly to a special cemetery to prevent spread. (Religious Leader 3, male, 61 years)

Communication about funeral protocols sometimes does not reach the public properly and clearly. Therefore, there are reactions, such as refusal to bury people. (Religious Figure 1, male, 43 years)

Community promotion was not extensively organized, contributing to rejection and forceful retrieval of corpses by community members. Scholars suggested the need for peaceful coordination among local governments, religious leaders, and 
the community on issues related to the COVID-19 protocol. However, the religious leaders highlighted the psychological impact of the changes to funerals. They stated that the government must consider the emotional impact of the changes in cultural values that have prompted the public to reject COVID-19 procedures.

It (the funeral process) should account for psychological factors. Once someone dies, they are carried away, not to be seen by their siblings or families. Try to imagine how the family would feel. (Religious Leader 1, male, 43 years)

Community leaders indicated that dialogue between the government and other parties provides an important educational opportunity. The humanist approach of religious leaders was seen through their identification of obstacles and possible solutions by considering the COVID-19 protocol and sharia rules. Furthermore, active participation by religious leaders in educating community members and overseeing religious services is important for the families of patients to prevent transmission and new clusters.

Dialogue and arguments are carried out with the government, and religious leaders have a role. Therefore, it (the COVID-19 burial protocol) could come to be understood and embraced by the person concerned with accepting the actual method of the funeral with this protocol. (Community Leader 1, male, 52 years)

\section{Discussion}

This study found that patients' families struggled to fully accept the diagnosis of COVID-19, which led to their rejection of new funeral protocols. This may have been exacerbated by misleading information about diagnoses from medical practitioners. Similarly, studies in Brazil found that distrust in medical care was caused by unclear communication between family members and medical staff (Cardoso et al., 2020; Luiz et al., 2017). Therefore, accurate information empathetically conveyed by medical staff to the families of critical patients is important in reducing family member distrust (Regaira-Martínez \& Garcia-Vivar, 2021).

Religious leaders play a significant role in guiding families experiencing sociological and psychological distress due to differences in the honoring of deceased bodies before and during the pandemic (Yardley \& Rolph, 2020). In the current pandemic, families cannot participate in funeral activities as they used to through touching, hugging, and kissing. Additionally, they cannot take part in rituals such as cleansing and wrapping the corpse (Jahangir \& Hamid, 2020). These rituals aim to honor the deceased and prepare them for acceptance in the afterlife, and they preserve cultural norms and allow the bereaved to express their feelings (Hamid \& Jahangir, 2020). Research in Kashmir, India, showed that more limited involvement in corpse care has a profound psychological impact on the family (Hamid \& Jahangir, 2020). Therefore, any revisions to how families can interact with bodies during funeral proceedings under COVID-19 protocols must be informed by the families themselves (mahram). 
This research confirmed that scholars from select Islamic community organizations agree that corpse care requires restrictions to prevent disease transmission. In Islam, similar opinions from distinguished intellectuals have been reported (Al-Shahri et al., 2007; Nielsen et al., 2015). Special treatment involves regular washing and preventing water from splashing onto those bathing the dead bodies (Lev, 2011; Petersen, 2013). Decision-making is carried out by medical personnel or authorized parties to identify cases diagnosed as having an infectious disease and requiring special care. Previous research has shown that corpse management with the assistance of a medical team prevents disease clusters (Lee-Kwan et al., 2017). Therefore, this medical support is necessary to avoid rejection of protocols and increase public confidence.

Islamic community organizations in Indonesia have implemented Ghoib prayers and restrictions on $t a$ 'ziah or online prayers as a substitute for funeral prayers. This is in line with scholarly responses, where the organizations' central management has formulated specific corpse care regulations with health protocols for hospitals and mosques. The Muhammadiyah Central Board issued a circular to all regional administrators to execute the necessary health protocols (Pengurus Pusat Muhammadiyah, 2020). In line with this, Ghoib prayers are offered to prevent disease transmission at funeral prayer places and ta'ziah activities. Furthermore, educating public and religious leaders is a comprehensive and cross-sectoral strategy for preventing COVID-19.

The cultural structure of Indonesian society is based on the religious community, with great respect paid to scholars. Additionally, Fatwas and scholarly opinions are references for worship implementation. Several studies show that intellectuals play important roles in health education (Cotton et al., 2006; Koenig, 2009; Rivera-Hernandez, 2014; Zou et al., 2009). However, various case reports have revealed that visiting family members of deceased patients/ta'ziah during the COVID-19 pandemic triggered new viral clusters (Nurhayati Tri Bayu Purnama, 2020; Purnama et al., 2020). Compliance with health protocols by community and religious leaders is a problem in controlling COVID-19 and facilitating religious worship.

The government showed interest in the opinions of scholars during this pandemic. This is evidenced by the involvement of scholars in enhancing public awareness of COVID-19 risks and reducing transmission associated with corpse preparation. A study in Iran found that social and moral support from religious leaders could help COVID-19-affected families deal more easily with deceased bodies (Yoosefi Lebni et al., 2021). The involvement of scholars in spreading new ideas and providing community assistance may indicate a personal concern for social problems. These religious leaders are deliberately presented on television or through social media and often worship at home. COVID-19 corpse management could be effective when medical protocols are employed to prevent the virus being spread to caregivers. Therefore, protection and respect for protocols may need to take precedence over traditional care for corpses to avoid endangering other people's lives. 


\section{Study Limitations}

This research could impact the involvement of religious leaders in funeral processes for COVID-19 patients. However, the results must be understood in the context of several limitations. This study could recruit only males as key participants (religious leaders) due to the influence of the patriarchal model in Indonesia. Furthermore, the spread of COVID-19 misinformation has affected the perceptions and responses of religious leaders, although the sources of this information and its dissemination were not explored in depth in this study. Therefore, further studies should be conducted to provide a deeper understanding of religious leaders' perceptions and responses.

\section{Conclusions}

These findings show the importance of understanding different scholars' perceptions and responses for preventing further COVID-19 spread through corpse handling. The religious nature of Indonesian society and the central role of scholars in public education hold promising potential to reduce transmission. Furthermore, comprehensive awareness raising and coordination reduce misperceptions and misinformation regarding corpse care based on the government's directives. Therefore, more successful implementation of these protocols would potentially impede new viral clusters.

Scholars' involvement in Indonesia is extensive, but they should support the government in educating the public on compliance with COVID-19 corpse care directives. This is line with health protocols and sharia rules for implementing emergency care provisions. Additionally, the regional development system and religious leaders' informal dialogue through mosques or Islamic centers educate individuals about corpse care. Furthermore, the training model and materials outlining new requirements related to COVID-19 should be modified based on Islamic principles.

\section{Declarations}

Conflict of interest The authors declare no competing interest is available on this study and compliance with ethical standard.

\section{References}

Ahaddour, C., Van den Branden, S., \& Broeckaert, B. (2017). Purification of body and soul for the next journey. Practices surrounding death and dying among muslim women. OMEGA - Journal of Death and Dying, 76(2), 169-200. https://doi.org/10.1177/0030222817729617

Ahmed Al-Dawoody, O. F. (2020). COVID-19 and Islamic burial laws: safeguarding dignity of the dead. International Committee of the Red Cross. https://blogs.icrc.org/law-and-policy/2020/04/30/covid19-islamic-burial-laws/ 
Ahmed, Q. A., Arabi, Y. M., \& Memish, Z. A. (2006). Health risks at the Hajj. Lancet, 367(9515), 10081015. https://doi.org/10.1016/S0140-6736(06)68429-8

Alimardani, M., \& Elswah, M. (2020). Online temptations: COVID-19 and religious misinformation in the MENA region. Social Media Society, 6(3), 2056305120948251. https://doi.org/10.1177/20563 05120948251

Al-Shahri, M. Z., Fadul, N., \& Elsayem, A. (2007). Death, dying and burial rites in Islam. European Journal of Palliative Care, 14(4), 164-167.

Al-Zubaydi, A. al-F. M. bin M. bin 'Abd al-W. al-H. (2001). Tâj al-'Arûs min Jawâhir al-Qâmûs. Saudi Arabia: al-Maktabah al-Syâmilah.

Charzyńska, E. (2015). Multidimensional approach toward spiritual coping: Construction and validation of the spiritual coping questionnaire (SCQ). Journal of Religion and Health, 54(5), 1629-1646. https://doi.org/10.1007/s10943-014-9892-5

Cotton, S., Puchalski, C. M., Sherman, S. N., Mrus, J. M., Peterman, A. H., Feinberg, J., Pargament, K. I., Justice, A. C., Leonard, A. C., \& Tsevat, J. (2006). Spirituality and religion in patients with HIV/ AIDS. Journal of General Internal Medicine, 21(Suppl 5), S5-S13. https://doi.org/10.1111/j.15251497.2006.00642.x

Cyphers, N. A., Clements, A. D., \& Lindseth, G. (2017). The Relationship between religiosity and healthpromoting behaviors in pregnant women. Western Journal of Nursing Research, 39(11), 1429-1446. https://doi.org/10.1177/0193945916679623

de Cardoso, É. A., da Silva, B. C., Santos, J. H., Lotério, L. D., Accoroni, A. G., \& Santos, M. A. (2020). The effect of suppressing funeral rituals during the covid-19 pandemic on bereaved families. Revista Latino-Americana De Enfermagem, 28(e3361), 1-9. https://doi.org/10.1590/1518-8345.4519.3361

Gao, Q., Hu, Y., Dai, Z., Xiao, F., Wang, J., \& Wu, J. (2020). The epidemiological characteristics of 2019 novel coronavirus diseases (COVID-19) in Jingmen, China. SSRN Electronic Journal. https://doi. org/10.2139/ssrn.3548755

Gray, P. B. (2004). HIV and islam: Is HIV prevalence lower among muslims? Social Science and Medicine, 58(9), 1751-1756. https://doi.org/10.1016/S0277-9536(03)00367-8

Hall, D. E., Meador, K. G., \& Koenig, H. G. (2008). Measuring religiousness in health research: Review and critique. Journal of Religion and Health, 47(2), 134-163. https://doi.org/10.1007/ s10943-008-9165-2

Hamid, W., \& Jahangir, M. S. (2020). Dying, death and mourning amid COVID-19 pandemic in Kashmir: A qualitative study. Omega (united States). https://doi.org/10.1177/0030222820953708

Hashmi, F. K., Iqbal, Q., Haque, N., \& Saleem, F. (2020). Religious cliché and stigma: a brief response to overlooked barriers in COVID-19 management. Journal of Religion and Health, 59(6), 2697-2700. https://doi.org/10.1007/s10943-020-01063-y

Hirji, S. (2020). The impact of Covid-19 on Islamic burial rites. GMJ Journal. https://www.gmjournal. co.uk/the-impact-of-covid-19-on-islamic-burial-rites

Indonesian COVID-19 task force. (2020). Situation report of COVID-19 in Indonesia. https://covid19. go.id/

Indonesian COVID-19 task force. (2021). Situation report of COVID-19 in Indonesia. https://covid19. go.id

Indonesian muslim council. (2020). Fatwa majelis ulama Indonesia No 14 Tahun 2020 tentang penyelenggaraan ibadah dalam situasi terjadi wabah COVID-19. https://mui.or.id/

Jahangir, M. S., \& Hamid, W. (2020). Mapping mourning among muslims of Kashmir: analysis of religious principles and current practices. Omega (united States). https://doi.org/10.1177/0030222820 911544

Koenig, H. G. (2009). Research on religion, spirituality, and mental health: A review. Canadian Journal of Psychiatry, 54(5), 283-291. https://doi.org/10.1177/070674370905400502

Lee-Kwan, S. H., DeLuca, N., Bunnell, R., Clayton, H. B., Turay, A. S., \& Mansaray, Y. (2017). Facilitators and barriers to community acceptance of safe, dignified medical burials in the context of an ebola epidemic, Sierra Leone, 2014. Journal of Health Communication, 22(sup1), 24-30. https:// doi.org/10.1080/10810730.2016.1209601

Lev, E. (2011). Ottoman Medicine, healing and medical institutions 1500-1700. By miri shefer-mossensohn pp. 277. Albany, State University of New York. Journal of the Royal Asiatic Society of Great Britain \& Ireland. https://doi.org/10.1017/s1356186311000137

Luiz, F. F., Caregnato, R. C. A., \& da Costa, M. R. (2017). Humanization in the intensive care: Perception of family and healthcare professionals. Revista Brasileira De Enfermagem, 70(5), 1040-1047. https://doi.org/10.1590/0034-7167-2016-0281 
Ma'luf, L. (1987). Al-Munjid fi al-Lughah. Dar al-Masyriq Beirut: Libanon.

Memish, Z. A., Stephens, G. M., Steffen, R., \& Ahmed, Q. A. (2012). Emergence of medicine for mass gatherings: Lessons from the Hajj. The Lancet Infectious Diseases, 12(1), 56-65. https://doi.org/10. 1016/S1473-3099(11)70337-1

Moreira-Almeida, A., Neto, F. L., \& Koenig, H. G. (2006). Religiousness and mental health: A review. Revista Brasileira De Psiquiatria, 28(3), 242-250. https://doi.org/10.1590/s1516-4446200600 5000006

Nielsen, C. F., Kidd, S., Sillah, A. R. M., Davis, E., Mermin, J., \& Kilmarx, P. H. (2015). Improving burial practices and cemetery management during an Ebola virus disease epidemic-Sierra Leone, 2014. Morbidity and Mortality Weekly Report, 64(1), 20-27.

Noden, B. H., Gomes, A., \& Ferreira, A. (2010). Influence of religious affiliation and education on HIV knowledge and HIV-related sexual behaviors among unmarried youth in rural central Mozambique. AIDS Care-Psychological and Socio-Medical Aspects of AIDS/HIV, 22(10), 1285-1294. https:// doi.org/10.1080/09540121003692193

Nurhayati Tri Bayu Purnama. (2020). Tokoh agama bisa berperan dalam cegah tindakan ambil paksa jenazah pasien COVID, ini caranya. The Conversation. https://theconversation.com/riset-tokohagama-bisa-berperan-dalam-cegah-tindakan-ambil-paksa-jenazah-pasien-covid-ini-caranya147095\#comment_2357005

Pane, M., Kong, F. Y. M., Purnama, T. B., Glass, K., Imari, S., Samaan, G., \& Oshitani, H. (2019). Indonesian hajj cohorts and mortality in Saudi Arabia from 2004 to 2011. Journal of Epidemiology and Global Health, 9(1), 11-18. https://doi.org/10.2991/jegh.k.181231.001

Pengurus Pusat Muhammadiyah. (2020). Edaran pimpinan pusat muhammadiyah nomor 02/EDR/ I.0/E/2020 Tentang tuntunan ibadah dalam kondisi darurat COVID-19. https:/covid19.muham madiyah.id/

Persynaki, A., Karras, S., \& Pichard, C. (2017). Unraveling the metabolic health benefits of fasting related to religious beliefs: A narrative review. Nutrition, 35, 14-20. https://doi.org/10.1016/j.nut. 2016.10.005

Petersen, A. (2013). The archaeology of death and burial in the Islamic World. Oxford University Press. https://doi.org/10.1093/oxfordhb/9780199569069.013.0014

Purnama, T. B., Khadijah, S., \& Sadri, I. (2020). How to handle the deceased body of COVID-19 an insight from Indonesian muslim burial handlers knowledge, perception, and practice. MedRxiv. https://doi.org/10.1101/2020.08.03.20167593

Regaira-Martínez, E., \& Garcia-Vivar, C. (2021). The process of giving information to families in intensive care units: A narrative review. Enfermeria Intensiva, 32(1), 18-36. https://doi.org/10.1016/j. enfi.2019.11.004

Rewar, S., \& Mirdha, D. (2014). Transmission of Ebola virus disease: An overview. Annals of Global Health, 80(6), 444-451. https://doi.org/10.1016/j.aogh.2015.02.005

Richards, P., Amara, J., Ferme, M. C., Kamara, P., Mokuwa, E., Sheriff, A. I., Suluku, R., \& Voors, M. (2015). Social pathways for Ebola virus disease in Rural Sierra Leone, and some implications for containment. PLoS Neglected Tropical Diseases, 9(4), e0003567. https://doi.org/10.1371/journal. pntd.0003567

Rivera-Hernandez, M. (2014). The role of Religious leaders in health promotion for older mexicans with diabetes. Journal of Religion and Health, 54(1), 303-315. https://doi.org/10.1007/ s10943-014-9829-z

The Republic of Indonesia Ministry of Religious Affairs. (2020a). Safe burial for COVID-19 cases (Protokol Pengurusan Jenazah Pasien COVID-19). https://covid19.go.id/p/protokol/kemenag-protokolpengurusan-jenazah-pasien-covid-19

The Republic of Indonesia Ministry of Religious Affairs. (2020b). Surat edaran menteri agama tentang panduan penyelenggaraan kegiatan keagamaan di rumah ibadah. https://covid19.go.id/p/regulasi/ surat-edaran-menteri-agama-nomor-15-tahun-2020

Tiffany, A., Dalziel, B. D., Kagume Njenge, H., Johnson, G., Nugba Ballah, R., James, D., Wone, A., Bedford, J., \& McClelland, A. (2017). Estimating the number of secondary Ebola cases resulting from an unsafe burial and risk factors for transmission during the West Africa Ebola epidemic. PLoS Neglected Tropical Diseases, 11(6), e0005491. https://doi.org/10.1371/journal.pntd.0005491

Trepanowski, J. F., \& Bloomer, R. J. (2010). The impact of religious fasting on human health. Nutrition Journal, 9(57), 1-9. https://doi.org/10.1186/1475-2891-9-57

Weiss, P., \& Murdoch, D. R. (2020). Clinical course and mortality risk of severe COVID-19. The Lancet, 395(10229), 1014-1015. https://doi.org/10.1016/S0140-6736(20)30633-4 
World Health Organization (WHO). (2020). COVID-19 situation report. https://www.who.int

Xinguang, C., \& Yu, B. (2020). First two months of the 2019 Coronavirus Disease (COVID-19) epidemic in China: real-time surveillance and evaluation with a second derivative model. Global Health Research and Policy. https://doi.org/10.1186/s41256-020-00137-4

Yardley, S., \& Rolph, M. (2020). Death and dying during the pandemic. The BMJ, 369, 1472. https://doi. org/10.1136/bmj.m1472

Yoosefi Lebni, J., Ziapour, A., Mehedi, N., \& Irandoost, S. F. (2021). The Role of clerics in confronting the COVID-19 crisis in Iran. Journal of Religion and Health. https://doi.org/10.1007/ s10943-021-01295-6

Zou, J., Yamanaka, Y., John, M., Watt, M., Ostermann, J., \& Thielman, N. (2009). Religion and HIV in Tanzania: Influence of religious beliefs on HIV stigma, disclosure, and treatment attitudes. BMC Public Health. https://doi.org/10.1186/1471-2458-9-75

Publisher's Note Springer Nature remains neutral with regard to jurisdictional claims in published maps and institutional affiliations. 